\title{
TIPOLOGI DAN KONSEP INTEGRASI PADA LINGKUNGAN BANGUNAN PENDIDIKAN DENGAN KARAKTER ARSITEKTUR KOLONIAL DI JALAN KARTINI KOTA SALATIGA
}

\author{
Sigit Ashar Setyoaji ${ }^{*}$, R. Siti Rukayah, Bambang Supriyadi \\ Program Studi Magister Teknik Arsitektur, Fakultas Teknik, Universitas Diponegoro, \\ Jl. Hayam Wuruk 5, Kampus Undip Pleburan, Semarang, Indonesia
}

\begin{abstract}
Abstrak
Bangunan cagar budaya adalah bangunan yang secara arsitektural memiliki kekhasan baik dari nilai arsitektural, estetika dan mewakili suatu simbol kebudayaan. Bangunan pendidikan di Jalan Kartini Salatiga merupakan sebuah komplek bangunan cagar budaya yang terdapat di Kota Salatiga, merupakan peninggalan kolonial Belanda, sehingga tidak mengherankan apabila bangunan tersebut memiliki karakter arsitektur kolonial yang membentuk identitas yang khas pada kawasan tersebut. Pembangunan selasar pendidikan di Jalan Kartini Kota Salatiga tidak terlepas dari status Kota Salatiga sebagai Kota Gemeente yang membuat Kota Salatiga maju dalam pembangunan fasilitas kotanya termasuk fasilitas pendidikan di Jalan Kartini yang diperuntukkan untuk orang pribumi. Perlu kiranya kini dilakukan sebuah studi mengenai tipologi dan konsep integrasi kawasan mengingat bangunan tersebut merupakan bangunan cagar budaya yang berada pada satu kawasan yang berdekatan, sebagai upaya peran aktif pelestarian bangunan cagar budaya dari segi akademis arsitektur. Untuk menjawab pertanyaan penelitian mengenai tipologi dan konsep integrasi pada kawasan bangunan pendidikan di Jalan Kartini Salatiga digunakan metode rekonstruksi baik secara bangunan maupun secara kawasan yang dilakukan dengan mencari data kesejarahan berupa foto maupun wawancara kepada narasumber yang kompeten. Dalam penelitian ini diketahui bahwa bangunan pendidikan di Jalan Kartini Salatiga merupakan tipologi bangunan arsitektur kolonial modern yang tidak memiliki integrasi dalam konsep penataan kawasannya.
\end{abstract}

Kata kunci : tipologi; integrasi; bangunan cagar budaya; arsitektur colonial; Jalan Kartini Salatiga

\begin{abstract}
[Title: Typologi and Integration Concept of Educational Building and Character of Colonial-based Architecture at Kartini's Street Salatiga] Heritage building is a building that has a specific kind of architectural value, aesthetic and represent of cultural values. Educational buildings at Kartini street Salatiga is a complex of heritage buildings located in Salatiga, its a Dutch colonial heritage, so it is not surprising that the buildings has architecture colonial character that forms a distinctive identity in that region. The development of education corridor in Kartini Street Salatiga cannot be sepparated that city's statusas a Gemeente city that makes the failities development in its citywas grow up rapidly, included educational facilities in Salatiga street, that build for home-grown peoples. It wolud need to know that doing a study about the typology and regional integration concept in view that the buildings is a heritage buildings that located on the adjacent region, as an active role of heritage building preservation in terms of academic architecture. This research used reconstruction method, both building reconstruction and region reconstruction, to answer the research question about the typology and integration concept in heritage buildings at Kartini street Salatiga, that conducted with found the data from the historical photos and interviews with competent respondent. Theconclusions of this research is the educational buildings on the Kartini street Salatiga has modern colonial architecture typologies and that do not have an integration concept in the arrangement region.
\end{abstract}

Keywords : typology; integration; heritage building; colonial architecture; Kartini Street Salatiga

\section{Pendahuluan}

Perkembangan Salatiga di bawah pemerintahan Hindia Belanda. Membuat status Kota Salatiga menjadi Kota Gemeentee, sehingga pembangunan di

\footnotetext{
*) Penulis Korespondensi.

E-mail: sigit_ashar@yahoo.co.id
}

Salatiga menjadi maju, berbagai fasilitas-fasilitas kemudian dibangun di Kota Salatiga, salah satunya adalah fasilitas pendidikan. Sebelum status Salatiga sebagai Gemeente, pendidikan di Salatiga hanya diperuntukkan bagi warga Eropa. Namun ketika status Kota Salatiga berubah menjadi Gemeente, fasilitas pendidikan warga pribumi di Salatiga mulai 


\section{Teknik, 36 (2), 2015, 111}

difokuskan, sehingga terbentuk koridor pendidikan Normaalschool. Terdapat tiga bangunan pada koridor tersebut, yaitu Normaalschool, Meisijis Kweekschool, dan MULO yang semuanya diperuntukkan untuk pribumi. Kini koridor tersebut menjadi jalan Kartini dan ketiga bangun tersebut telah berubah menjadi sekolah SMP N1, SMPN2, SMAN 3 dan SDN Salatiga 05 yang kesemua bangunan tersebut kini juga menjadi bangunan cagar budaya.

Bangunan Cagar Budaya sendiri menurut Feilden (1994), adalah sebuah bangunan yang memiliki kekhasan yang mampu membuat kagum dan dapat dijadikan objek studi mengenai manusia dan kebudayaan yang membangun bangunan tersebut. Bangunan cagar budaya harus memiliki nilai arsitektural, estetika, sejarah, dokumentasi, arkeologi, ekonomi, sosial-politik, serta nilai simbolis dan spiritual, dan merupakan simbol dari sebuah identitas budaya. Jadi dalam sebuah bangunan cagar budaya tersebut banyak nilai-nilai yang mampu menjadi karakteristik tidak hanya pada bangunan tersebut namun juga terhadap kebudayaan, kawasan bahkan negara tempat bangunan cagar budaya itu berdiri. Menurut Utomo (2005), bentukan fisik sebuah karya arasitektural dapat menjadi ciri untuk lingkungan sekitarnya, yang banyak ditentukan oleh wujud desain dan perletakan yang dikaitkan dengan hubungan tiap elemen fisiknya.

Sebagai bangunan cagar budaya, bangunanbangunan pendidikan dengan karakter arsitektur kolonial di Jalan Kartini (Gambar 1) yang meliputi bangunan SMP Negeri 1 Salatiga, SMP Negeri 2 Salatiga, SMA Negeri 3 Salatiga, dan SD Negeri Salatiga 05 tentu memiliki nilai khas yang membentuk nilai identitas baik secara kawasan, maupun Kota Salatiga yang patut untuk kemudian dilestarikan keberadaannya, sehingga perlu untuk kemudian dilakukan studi tipologi sebagai sebuah bagian dari upaya pelestarian bangunan cagar budaya pendidikan di sepanjang Jalan Kartini Kota Salatiga.

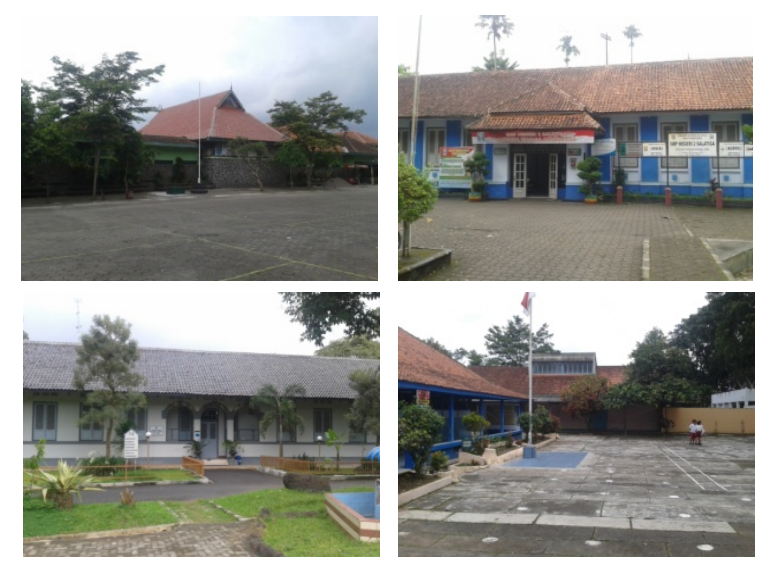

Gambar 1. Bangunan Pendidikan dengan Karakter Kolonial di Jalan Kartini Salatiga (Dokumentasi Penulis, 2015)
Menurut Lang (2005) tipologi adalah ilmu atau kegiatan studi atau teori untuk mencari jenis dan mengklasifikasi sebuah objek dan harus didasarkan pada variabel-variabel terkait yang mampu menjelaskan fenomena sebuah objek dalam konteks ini adalah objek arsitektural. Sehingga studi tipologi dirasa perlu untuk kemudian dilakukan terhadap lokus penelitian sebagai sebuah bangunan cagar budaya untuk mengidentifikasi dan menganalisa tiap elemenelemen bangunannya.

Sebagai sebuah koridor pendidikan yang letak bangunan pendidikan satu dengan lainnya saling berdekatan, bangunan-bangunan pendidikan di jalan Kartini yang dibangun pada masa pemerintahan Hindia-Belanda di Kota Salatiga dimungkinkan terdapat konsep integrasi lingkungan yang diterapkan pada kawasan pendidikan di Jalan Kartini Kota Salatiga. Seperti diketahui, menurut Kamus Besar Bahasa Indonesia, Integrasi adalah pembauran sehingga dapat menjadi satu kesatuan yang utuh dan bulat. Di dalam ilmu arsitektur atau seni bangunan, konsep integrasi digunakan untuk menata elemenelemen bangunan atau arsitektural sehingga mencapai suatu tatanan komposisi yang ideal. Sehingga di dalam penelitian ini diharapkan mampu menguak konsep tatanan secara kawasan bangunan-bangunan pendidikan dengan karakter arsitektur kolonial yang merupakan bangunan cagar budaya di Jalan Kartini Kota Salatiga.

Hal-hal tersebut di atas didasarkan pada pasal 79 UU RI No.11 Tahun 2010 tentang Cagar Budaya, ayat 1 (UU 2010), bahwa "Penelitian dilakukan pada setiap rencana pengembangan Cagar Budaya untuk menghimpun informasi serta mengungkap, memperdalam, dan menjelaskan nilai-nilai budaya. Dan pada ayat 3, tertulis proses dan hasil Penelitian Cagar Budaya sebagaimana dimaksud pada ayat (2) dilakukan untuk kepentingan meningkatkan informasi dan promosi Cagar Budaya. Jadi dapat disimpulkan, studi tipologi dan konsep integrasi pada bangunan pendidikan di Jalan Kartini Salatiga untuk menjelaskan nilai-nilai budaya yang dilihat menurut ranah disiplin ilmu arsitektur, sebagai bagian peran aktif pelaksanaan pelestarian cagar budaya dari segi akademis arsitektur. Hal tersebut diperkuat oleh Firzal (2011), penelitian tipologi berfungsi sebagai pembuka pengertian serta pemahaman mengenai karakter hidup masyarakat yang berkembang, sikap dan nilai budaya merupakan pembentuk dalam nilai-nilai rancang bangun yang akan terus berkembang, jadi melakukan studi tipologi berguna untuk memahami suatu karakter rancang bangun yang didasari oleh sistem kebudayaan.

Dari latar belakang tersebut kemudian dapat dirumuskan pertanyaan penelitian yang coba kemudian untuk dijawab. Bagaimana tipologi bangunan pendidikan di Jalan Kartini Salatiga sebagai sebuah bangunan cagar budaya dengan karakter arsitektur kolonial yang perlu dilestarikan? Apakah ada konsep integrasi antar bangunan diterapkan dalam desain kawasan bangunan pendidikan di Jalan Kartini 


\section{Teknik, 36 (2), 2015, 112}

Salatiga, mengingat keempat bangunan tersebut berada di dalam satu koridor?

Diharapkan melalui penelitian Tipologi dan Konsep Integrasi pada Lingkungan Bangunan Pendidikan dengan Karakter Arsitektur Kolonial di Jalan Kartini Salatiga ini, selain sebagai upaya peran aktif pelestarian cagar budaya juga dapat dijadikan masukan kepada lokus penelitian sebagai sebuah pertimbangan dalam melakukan upaya pengembangan yang tetap memperhatikan karakter bangunan sebagai sebuah bangunan cagar budaya. Diharapkan pula penelitian ini menjadi penelitian berseri yang menjadi dasar untuk penelitian-penelitian serupa lainnya dikemudian hari.

\section{Tipologi dan Konsep Integrasi pada Bangunan Kolonial}

\subsection{Kajian Tipologi}

Tipologi adalah adalah usaha untuk kemudian mengelompokan serta mengklasifikasikan sebuah objek bedasarkan identifikasi tipe yang memiliki kesamaan identitas. Menurut Faisal (2014), tipologi adalah ilmu dan pengetahuan yang memfokuskan ke aspek identifikasi tipe serta karakteristik dan pengklasifikasian atau pengelompokan sebuah objek atau dapat pula disebut sebagai taksonomi.

Menurut Sukada dalam Budiharjo (1997, ed), langkah dalam studi tipologi :

- Menentukan bentuk dasar

- Menentukan sifat dasar

- Mempelajari proses perkembangan

Sebuah objek arsitektural dalam hal ini berupa artefak adalah sebuah hasil karya manusia dalam periode waktu tertentu yang kemudian menciptakan nilai karakter tersendiri yang mungkin berbeda dengan sebuah objek arsitektur pada masa-masa periode waktu lainnya.

\subsection{Konsep Integrasi}

Di dalam bukunya Ching (2000), menyebutkan suatu susunan yang harmonis dapat diciptakan dengan menata suatu kondisi di mana setiap bagian dari seluruh komposisi arsitektural saling berhubungan, tidak hanya sebuah aturan geometris semata. Dari pemaparan di atas maka dapat disimpulkan bahwa untuk mencapai tatanan yang harmonis dan selaras atau menyatu diperlukan sebuah prinsip-prinsip tatanan yang sesuai dengan prinsip-prinsip visual.

Untuk mencapai tatanan yang selaras, menurut Ching (2000), perlu diperhatikan prinsip dasar penataan, yaitu: sumbu, simetri, hierarki, datum, irama, dan transformasi.

\subsection{Perkembangan Arsitektur Indonesia di Jaman Kolonial Belanda}

Menurut Handinoto (2010), tipikal arsitektur kolonial di Indonesia dapat dibedakan sebagai berikut:

1. Indische Empire Style

a. Denah
Bentuk denah simestris penuh. Teras yang mengelilingi bangunan berguna juga sebagai barrier.

b. Tampak

Didominasi barisan kolom gaya Yunani.

c. Bahan Bangunan

Bahan utamanya adalah batu bata.

d. Sistem kontruksi

Sistem konstruksi dinding pemikul

2. Arsitektur Peralihan

a. Denah

Bentuk denah simestris penuh. Teras yang mengelilingi bangunan berguna juga sebagai barrier.

b. Tampak

Didominasi barisan kolom gaya Yunani mulai menghiang.

c. Bahan Bangunan

Bahan utamanya adalah batu bata.

3. Arsitektur Kolonial Modern
a. Denah
Bentuk denah lebih bervarisi.

b. Tampak

Tampak menggunakan clean design sesuai dengan anjuran form follow function.

c. Bahan Bangunan

Sudah menggunakan kaca.

d. Sistem kontruksi

Sistem struktur beton.

\section{Metode Penelitian}

Dalam penelitian ini, analisa mencoba untuk menjawab pernyataan mengenai tipologi dan konsep integrasi bangunan pendidikan dengan studi kasus bangunan pendidikan di Jalan Kartini Kota Salatiga (Gambar 2). Di dalam penamaan bangunan pada lokus penelitian digunakan penamaan bangunan pada masa awal bangunan pendidikan di Jalan kartini Kota Salatiga didirikan, di dalam proses penamaan bangunan ini mempengaruhi analisa tipologi bangunan serta analisa integrasi karena dalam proses analisa fungsi bangunan pada awal desainnya menjadi pertimbangan dalam anlisa untuk menjawab pertanyaan penelitian. Sehingga dengan menggunakan penamaan bangunan pendidikan di Jalan Kartini menggunakan nama awal akan mempermudah nantinya dalam proses analisa.

Langkah-langkah dalam analisa sebagaimana telah disebutkan di atas dapat dituliskan secara rinci dalam urutan sebagai berikut :

\section{a. Identifikasi dan analisa bentuk bangunan mula dengan cara pengelupasan}

Seperti telah dijelaskan di dalam metode studi tipologi oleh Wijanarka (2001), studi tipologi diawali dengan identifikasi bentuk awal mula untuk mengetahui sifat dasar yang terkandung dalam objek, jadi dalam penelitian ini, langkah awal dalam penelitian ini adalah mencoba mengelupas bangunanbangunan sekolah baik SMP Negeri 1 Salatiga (MULO), SMP Negeri 2 Salatiga (Meisijis Kweekschool), SMA Negeri 3 Salatiga, serta SD 


\section{Teknik, 36 (2), 2015, 113}

Negeri Salatiga 05 (Normaalschool) seperti atau mendekati keadaan awal bangunan tersebut. Langkah ini dilakukan berdasarkan analisa karakter pada bangunan serta interview kepada responden yang memahami kesejarahan terutama terkait bangunan objek penelitian.

\section{b. Identifikasi dan analisa Karakter Elemen- Elemen Bangunan Pendidikan sebagai Bangunan Cagar Budaya}

Dengan melakukan analisa karakter dan elemen bangunan Pendidikan sebagai sebuah bangunan cagar budaya nantinya akan diketahui karakter apakah yang muncul pada bangunan tersebut, analisa ini didasarkan pada hasil observasi dari lapangan yang telah dilakukan penggambaran kembali oleh peneliti serta telah melakukan proses analisa pengelupasan ke wujud awal bangunan. Hal-hal yang coba dianalisa pada bagian ini adalah lay-out, tampak bangunan, bahan bangunan, sistem konstruksi, dan ornamen dekoratif bangunan.

\section{c. Analisa studi tipologi bangunan cagar budaya}

Analisa studi tipologi bangunan ini diharapkan dapat mengetahui klasifikasi serta tipe bangunan pendidikan di Jalan Kartini Kota Salatiga dengan karakter arsitektur kolonial sebagai sebuah bangunan cagar budaya. Bagaimana tipologi bangunan tersebut berperan terhadap fungsi bangunan itu sendiri serta pembentukan identitas karakter kawasan koridor Jalan Kartini. Pendekatan proses kesejarahan dijadikan pedoman serta background dalam proses pikir penelitian. Dengan penelitian ini diharapkan mampu menemukan karakter serta identitas kawasan Jalan Kartini yang dibentuk oleh bangunan pendidikan di koridor jalan tersebut sebagai cagar budaya.

\section{d. Analisa konsep integrasi pada lingkungan bangunan cagar budaya}

Dalam analisa konsep integrasi pada kawasan lingkungan bangunan pendidikan dengan karakter arsitektur kolonial di Jalan Kartini Salatiga hal yang dilakukan pertama adalah melakukan rekonstruksi kawasan. Rekonstruksi kawasan ini dilakukan untuk mencari bentuk tatanan asli atau awal lingkungan bangunan pendidikan di Jalan Kartini Kota Salatiga. Proses rekonstruksi ini didasarkan pada data yang diperoleh melalui wawancara kepada narasumber yang kompeten serta bukti-bukti kesejarahan berupa foto, maupun peninggalan-peninggalan secara fisik bangunan yang mampu dijadikan acuan dalam proses rekonstruksi. Analisa kemudian dilakukan dengan pembuatan site plan dengan pendekatan teori figure ground sehingga terlihat antara massa solid bangunan dan void atau lahan terbuka (Gambar 3). Setelah itu dilakukan analisa pola hubungan ruang pada kawasan tersebut dengan mengidentifikasi bentuk site plan kawasan asli dan melakukan pengamatan terkait elemen-elemen penghubung. Analisa konsep pola integrasi lingkungan bangunan diteliti menurut aspekaspek penataan arsitektural seperti sumbu, simetri, hierarki, datum, irama, dan transformasi kawasan lingkungan bangunan pendidikan di Jalan Kartini Salatiga.

\section{Hasil dan Pembahasan}

\subsection{Selasar Pendidikan Kartini Salatiga}

Selain di kawasan Jalan Diponegoro sebagai penyumbang bangunan cagar budaya terbanyak di kota Salatiga, di sepanjang jalan Kartini Salatiga atau dulunya bernama Normallschollweg, juga terdapat beberapa bangunan cagar budaya. Berbeda dengan Jalan Diponegoro yang didominasi oleh bangunan pemerintahan dan kemiliteran, bangunan di sepanjang Jalan Kartini kesemuanya adalah bangunan yang dipergunakan untuk sekolah atau pendidikan. Bangunan-bangunan cagar budaya di sepanjang Jalan Kartini seperti SD N 05 Salatiga (SD Jenglong), SMA Negeri 3 Salatiga, SMP Negeri 1 dan SMP Negeri 2 Salatiga masih kokoh berdiri hingga sekarang.

Tertulis di dalam buku Sejarah Bangunan Cagar Budaya di Kota Salatiga yang diterbitkan oleh Dishubkombudpar Kota Salatiga (2013), perkembangan kawasan Jalan Kartini sebagai sebuah kawasan pendidikan tidak terlepas dari sejarah status Kota Salatiga itu sendiri. Sebelum pembentukan dewan-dewan daerah pada tahun 1917 dan Salatiga belum berstatus sebagai sebuah Gemeente, pendidikan di Kota Salatiga hanya diperuntukkan untuk orangorang Eropa saja dan hanya setingkat Sekolah Dasar (sekarang). Bangunan-bangunan sekolah pada masa itu seperti ELS (Eropeech Lager School), HIS (Hollande Inlander School), PHIS (Partikelir Hollands Inlander School), maupun HCS (Holland Chinese School). Namun sejak status Salatiga berubah menjadi Gemeente yang dipimpin oleh seorang Burgermister (Walikota), maka di kawasan Jalan Kartini atau normallschoolweg direncanakan untuk didirikan sekolah-sekolah umum untuk pribumi, seperti Normaalschool, Meisijis Kweekschool, dan MULO. Kedatangan istri gubernur Jenderal Limburg Stirum pada tahun 1919 dimanfaatkan untuk peresmian perltakan batu pertama di sekolah-sekolah yang direncanakan. Pemilihan lokasi di jalan Kartini sendiri juga tidak terlepas dari jaraknya yang dekat dengan kawasan bermukim orang pribumi di Kota Salatiga pada masa pemerintahan Hindia-Belanda, yang menurut Supangkat (2010), permukiman warga pribumi di Kota Salatiga tersebar di Pancuran, Kalioso, Gendongan dan Kalicacing

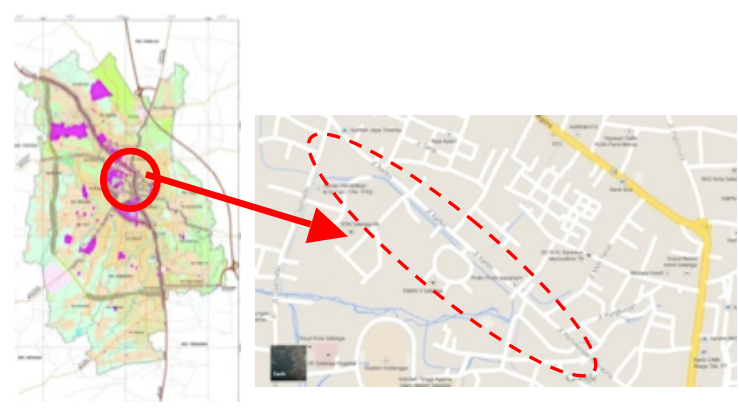

Gambar 2. Lokasi Penelitian (Sketsa Penulis, 2015) 


\section{Teknik, 36 (2), 2015, 115}

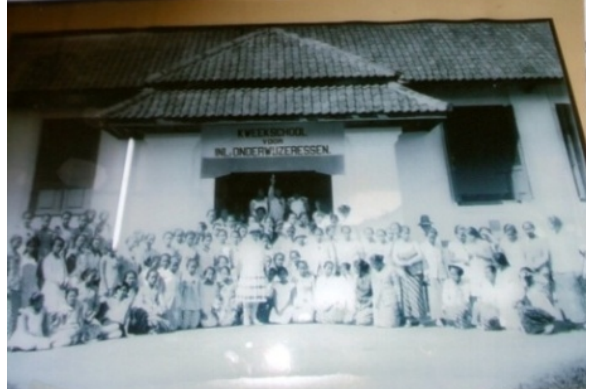

Gambar 6. Foto Lama bangunan Meisijis Kweekschool atau kini SMP Negeri 2 Salatiga (Dishubkombudpar Kota Salatiga, 2013)

Bangunan SMP Negeri 2 Salatiga atau dulunya Meisijis Kweekschool masuk ke dalam inventarisasi bangunan cagar budaya Kota Salatiga dengan nomor inventaris 11-73/Sla/071. Bangunan lama SMP Negeri 2 Salatiga berbentuk bujur sangkar dengan bangunan aula di tengahnya. Secara estetika arsitektural bangunan ini mencirikan bangunan arsitektur kolonial. Dilihat dari bentuk penataan lay-out denah bangunan yang tertata dengan rapi simetris.
Berdasarkan Gambar 7 dapat dianalisa bahwa bangunan Meisijis Kweekschool secara fasad berbentuk simetri yang menunjukkan bahwa bangunan tersebut menggunakan norma form follow function. Penggunaan material bata serta penggunaan atap dengan tritisan mengindikasikan bahwa bangunan tersebut menggunakan gaya arsitektur kolonial modern dengan mencoba merespon kontekstual Indonesia. Elemen pada bangunan Meisijis Kweekschool menunjukkan gaya arsitektur kolonial modern dimana elemen-elemen tersebut mencoba merespon iklim setempat seperti penggunaan jendela krepyak. Penggunaan elemen bukaan serta kolom menunjukkan bentuk sesuai dengan kebutuhan fungsinya, serta ornamen yang minimalis semakin memperkuat anaiisa di atas. Lay-out bangunan Meisijis Kweekschool merupakan bentuk tatanan tropis, dimana ruang-ruang kelas ditata secara radia mengelilingi inner court. Hal tersebut juga bahwa desain bangunan Meisjis Kweekschool ini mencoba merespon kondisi iklim tropis Indonesia dengan desain tata lay-out nya, yang merupakan ciri gaya arsitektur kolonial.

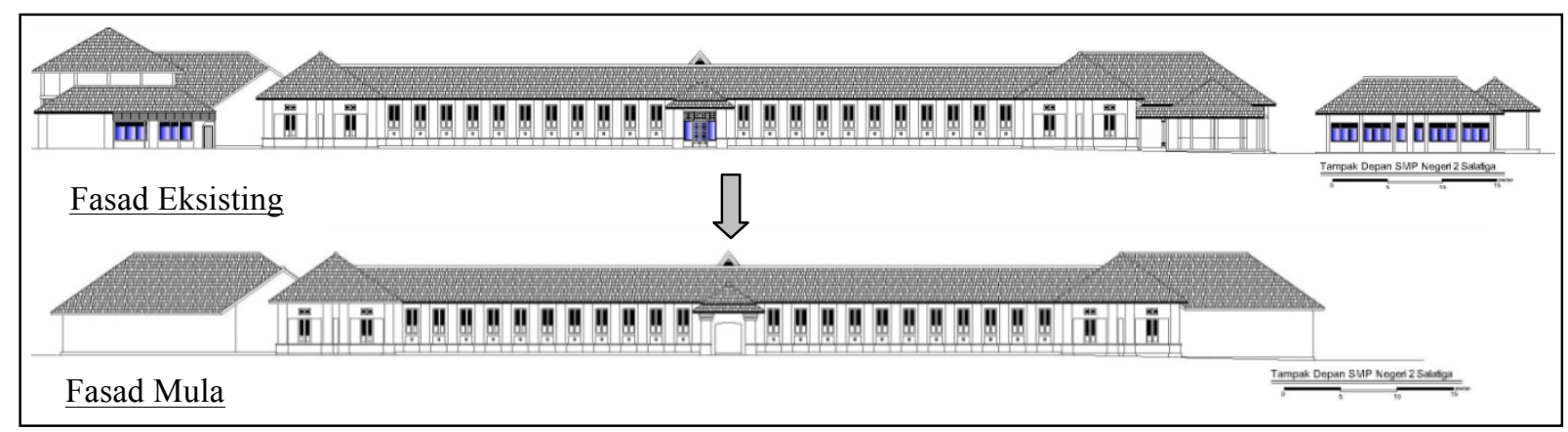

Gambar 7. Rekonstruksi Fasad Meisijis Kweekschool (Sketsa Penulis, 2015)

\section{c. Normaalschool}

Tertulis di dalam buku Sejarah Bangunan Cagar Budaya di Kota Salatiga oleh Dishubkombudpar Salatiga (2013), awal mula gedung SMA Negeri 3 ini dibangun untuk dipergunakan sebagai sebuah bangunan Indische Kweekschool (HIK). Hasil pendidikan HIK ini dipersiapkan sebagai guru atau tenaga pendidikan Sekolah Rakyat (SR) di daerahdaerah, maka dibangunlah sebuah sekolah HIK di Kota Salatiga dengan sistem pendidikan asrama yang diwajibkan bagi para siswa sekolah tersebut. Lahan yang luas pada area bangunan tersebut dapat dimanfaatkan sebagai asrama baik putra maupun putri yang terpisah, rumah-rumah dinas bagi pengajar, lapangan olahraga, dan aula kesenian. Direktur terakhir dari HIK adalah van den Bar.

Bangunan Normaalschool ini kini terbagi menjadi dua bangunan yang pertama adala SMA N 3 Salatiga Salatiga masuk ke dalam iventarisasi bangunan cagar budaya kota Salatiga dengan nomor inventaris 11-73/Sla/072 sedangkan yang kedua menjadi Bangunan SD Negeri Salatiga 05 ini terdaftar dalam inventarisasi bangunan cagar budaya di Kota Salatiga dengan nomor 11-73/Sla/112. Seperti telah dijelaskan sebelumnya masaa bangunan sekolah ini terpencar satu sama lain sehingga memiliki lahan yang cukup luas. Secara arsitektural bangunan Normaalschool ini bercirikan arsitektur kolonial. Terlihat dari penggunaan material-material bangunan yang didominasi dengan penggunaan dinding bata yang tebal dikarenakan berfungsi sebagai penopang struktur atap, penggunaan jendela yang lebar, serta ornamen-ornamen pada fasade bangunan yang semakin memperkuat karakter arsitektur kolonial pada bangunan tersebut.

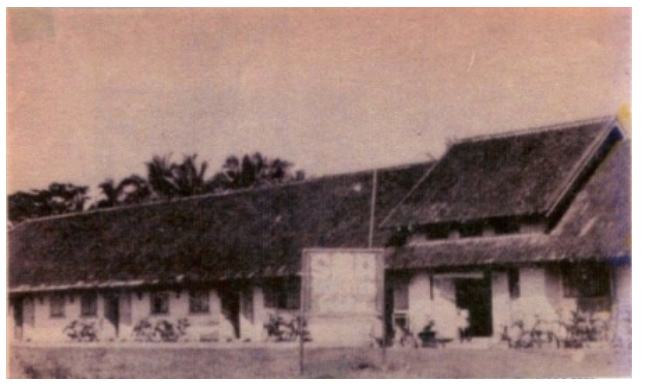

Gambar 8. Foto Lama bangunan Normaalschool atau kini SMA Negeri 3 Salatiga (Dishubkombudpar Kota Salatiga, 2013) 


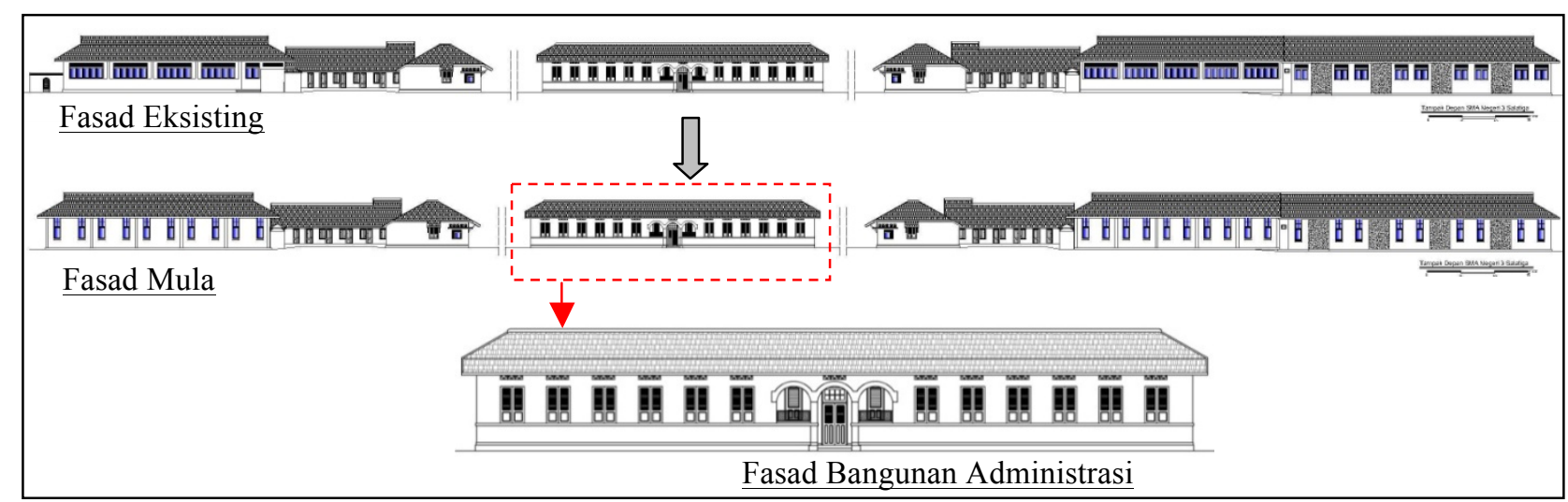

Gambar 9. Rekonstruksi Fasad Normaalschool (Sketsa Penulis, 2015)

Berdasarkan Gambar 9 dapat dianalisa bahwa bangunan Normaalschool secara secara fasad berbentuk simetri yang menunjukkan form follow function. Penggunaan material bata, serta terdapat material kaca serta penggunaan atap dengan tritisan mengindikasikan bahwa bangunan tersebut menggunakan gaya arsitektur kolonial modern dengan mencoba merespon kontekstual Indonesia. Elemen pada bangunan Normaalschool menunjukkan gaya arsitektur kolonial modern dimana elemen-elemen tersebut mencoba merespon iklim setempat seperti penggunaan jendela krepyak, serta penggunaan material kaca. Penggunaan elemen bukaan menunjukkan bentuk sesuai dengan kebutuhan fungsinya, serta ornamen yang minimalis semakin memperkuat anaiisa tersebut. Lay-out bangunan Normaalschool merupakan bentuk tatanan tropis, dimana ruang-ruang ditata menyebar dan rasio ruang luar lebih luas dari pada massa bangunannya, sehingga tatanan lay-out tersebut mencoba merespon iklim tropis di Indonesia.

\section{d. Tipologi Elemen dan Ornamen Bangunan}

Berdasarkan pengamatan dan analisa di atas. maka tipologi atau pengklasifikasian elemen-elemen bangunan pendidikan dengan karakter kolonial di Jalan Kartini Kota Salatiga dapat dikategorikan dalam beberapa klasifikasi atau tipe, yaitu :

\section{Elemen Ornamentasi Atap}

Ornamen atap berupa menara lonceng dan kisis-kisi pada gevel atap hanya terdapat pada bangunan MULO (Gambar 10).
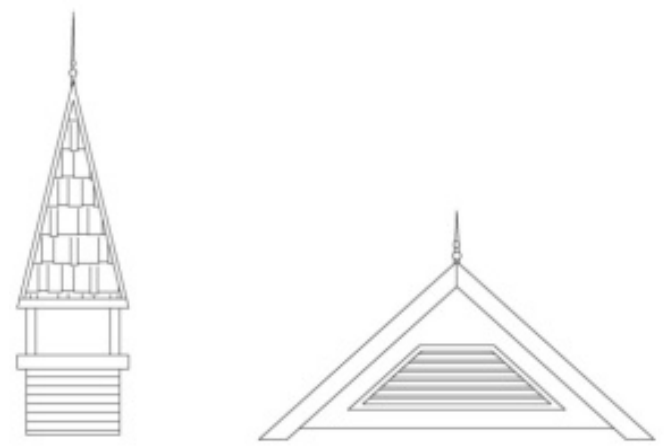

Gambar 10. Ornamen Atap (Sketsa Penulis, 2015)

\section{Elemen Bukaan Pintu}

Elemen pintu P1, P2, dan P3 merupakan tipikal pintu Normaalschool, yang tertlihat pada fasad depan bangunan bangunan tersebut (Gambar 11).

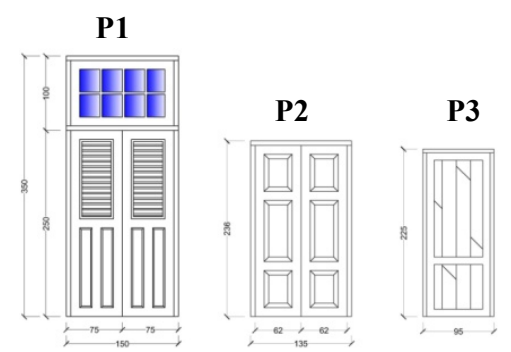

Gambar 11. Elemen Pintu (Sketsa Penulis, 2015)

Elemen Bukaan Jendela

Elemen jendela $\mathbf{J 1}$, merupakan tipikal jendela pada bangunan MULO dan Normaalschool. Jendela J2 dan J4, merupakan tipikal jendela Meisijis Kweekschool dan Normaalschool. Jendela J3, J5, J6, J7, J8 merupakan tipikal jendela bangunan Normaalschool (Gambar 12).

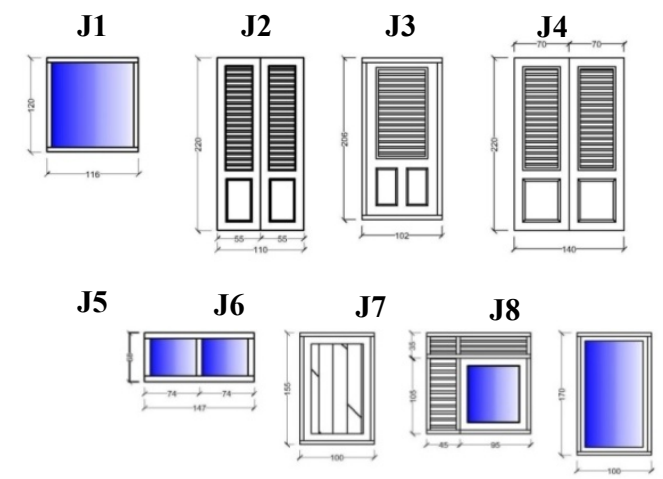

Gambar 12. Elemen Jendela (Sketsa Penulis, 2015)

Elemen Bukaan Boven

Elemen boven B1, merupakan tipikal bukaan boven bangunan Meisijiskweekschool, sedangkan elemen boven B2, merupakan tipikal boven bangunan Normaalschool (Gambar 13). 


\section{Teknik, 36 (2), 2015, 117}

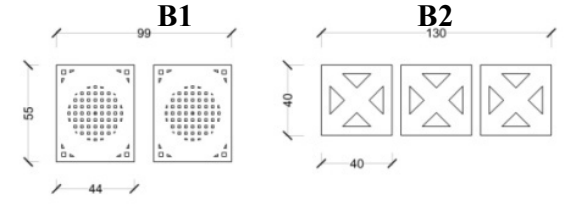

Gambar 13. Elemen Bukaan Boven (Sketsa Penulis, 2015)

Elemen Kolom Bangunan

Elemen kolom K1 dan K2 merupakan tipikal kolom bangunan Meisijiskweekschool, sedangkan elemen kolom K3, merupakan tipikal kolom bangunan Normaalschool (Gambar 14).

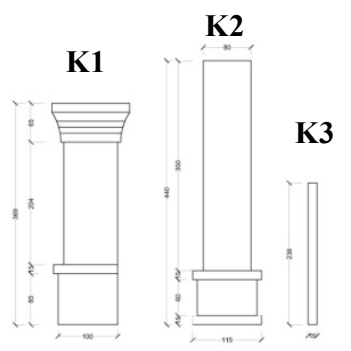

Gambar 14. Elemen Kolom (Sketsa Penulis, 2015)

Ornamen Bukaan (Gambar 15)
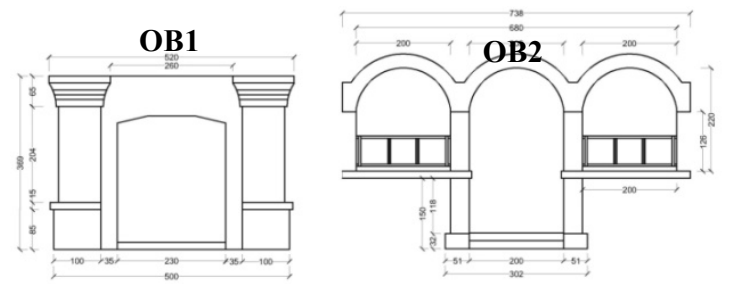

Gambar 15. Ornamen Bukaan (Sketsa Penulis, 2015)

\subsection{Analisa Konsep Integrasi Kawasan}

Seperti telah dijelaskan di atas, pada analisa konsep pola integrasi kawasan, diperlukan rekonstruksi awal kawasan bangunan pendidikan dengan karakter arsitektur kolonial di jalan Kartini Salatiga, sehingga diketahui pola tatanan site-plan kawasan tersebut untuk kemudian dianalisa pola tatanan berdasarkan analisa konsep integrasi kawasannya. Gambar rekonstruksi kawasan dapat dilihat pada Gambar 16.

Dari Gambar 16 dapat dianalisa bangunan pendidikan pada kawasan tersebut menggunakan pola linkage compositional form. Pola tatanan tersebut lebih menonjolkan tatanan bangunan sebagai sebuah individu di dalam sebuah kawasan yang cenderung melihat fungsional dari bangunan per bangunan. Jalan penghubung ketiga bangunan berupa koridor menjadi linkage visual kawasan tersebut (lihat Gambar 16.c), yang menjadi pengikat kawasan tersebut. Bangunan kelas dan bangunan sekolah latihan menjadi penghubung struktural massa pada kawasan bangunan tersebut. Pola linkage struktural yang dipakai pada kawasan tersebut merupakan tipikal linkage tambahan dimana pola tatanan tersebut melanjutkan pola pembangunan yang sudah ada.

Sumbu pada komplek bangunan tidak terikat satu dengan yang lainnya. Bangunan-bangunan pada kawasan tersebut didesain secara parsial atau terpisahpisah, tidak terdapat koneksi garis sumbu yang kuat pada kawasan bangunan pendidikan tersebut. Hal ini terkait dengan tipikal fungsi bangunan pendidikan pada kawasan tersebut yang berbeda-beda. Demikian pula dengan pola garis simetri, garis simetri cenderung merupakan garis simetri tiap bangunan yang memang tipikal bangunan kolonial. Garis simetri cenderung terpisah-pisah tiap bangunan, menjadikan kawasan tersebut tidak memiliki garis simetri yang menjadi acuan dalam mendesain bangunan-bangunan pada site pendidikan di Jalan Kartini Kota Salatiga. Bangunanbangunan pendidikan di Jalan Kartini Kota Salatiga didesain dengan konsep yang terpisah.

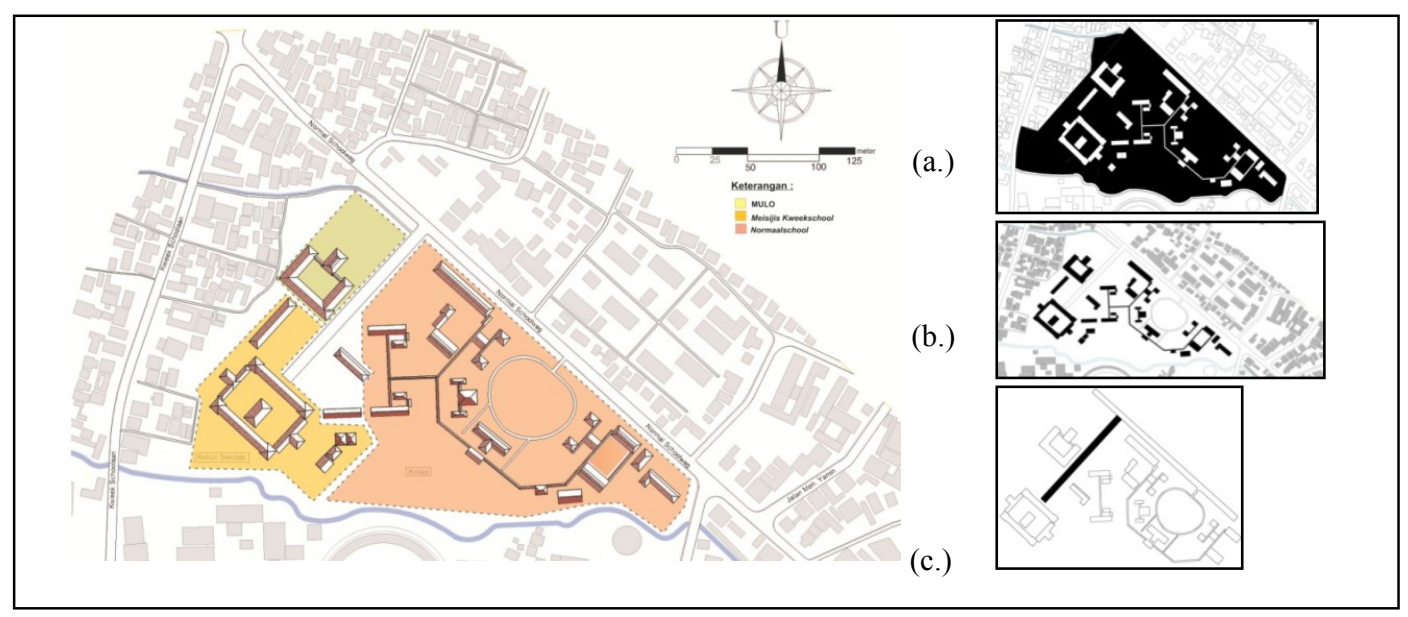

Gambar 16. Site-plan Hasil Rekonstruksi Kawasan Bangunan Pendidikan di Jalan Kartini Salatiga. a.) Komposisi Solid Void, b) Figure Ground Kawasan, c) Pola Linkage Kawasan (Sketsa Penulis, 2015)

Datum pada kawasan tersebut terdapat pada selasar atau koridor jalan yang menghubungkan bangunan MULO dengan bangunan Meisijis
Kweekschool (lihat Gambar 16.c), namun datum tersebut juga menghubungkan dengan bangunan Normaalschool walaupun secara orientasi bangunan 


\section{Teknik, 36 (2), 2015, 118}

Normaalschool tidak menghadap ke koridor tersebut. Secara tatanan datum tersebut menjadi pegikat ketiga massa bangunan tersebut.

Penggunaan elemen fasad bangunan yang variatif tidak dibarengi dengan tatanan yang memiliki pola yang teratur, sehingga ritme secara kawasan tidak terjadi secara harmonis (Gambar 17). Walaupun demikian menara lonceng merupakan vocal point pada bangunan MULO merupakan vocal point penanda bagi bangunan itu sendiri bukan merupakan hierarki tertinggi pada kawasan tersebut, mengingat bangunan pada kawasan jalan Kartini memiliki derajat tingkatan yang sama sebagai sebuah bangunan pendidikan.

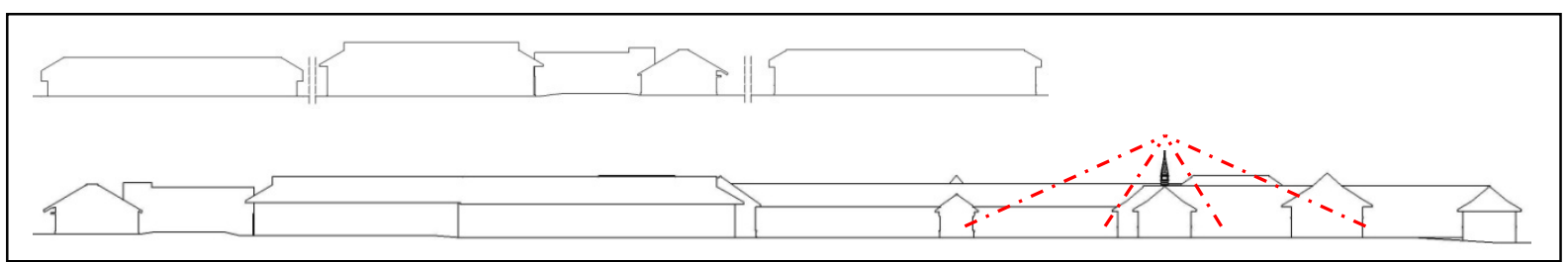

Gambar 17. Skematik pola tatanan serial vision fasad massa pada kawasan pendidikan Jalan Kartini Kota Salatiga (Sketsa Penulis, 2015)

\section{Kesimpulan}

Bangunan-bangunan pendidikan pada Jalan Kartini Kota Salatiga merupakan tipologi bangunan dengan gaya arsitektur kolonial modern. Penggunaan elemen-elemen bangunan yang mencoba mersepon kondisi kontekstual tropis Indonesia, penggunaan ornamen krepyak yang merupakan bentuk adaptasi dari arsitektur tradisional pada elemen jendela dan pintu, serta pengenalan material-material jenis baru seperti kaca pada elemen jendela memperkuat analisa tersebut, namun pada bangunan SMP Negeri 1 Salatiga atau bangunan MULO terdapat unsur pengulangan atau penambahan elemen ornamentasi menara atap yang merupakan tipikal gaya arsitektur peralihan, sehingga dapat dikatakan terjadi eksplorasi perpaduan gaya atau peralihan gaya arsitektur pada bangunan SMP Negeri 1 Salatiga atau bangunan MULO.

Tidak ditemukan konsep integrasi pada lingkungan bangunan pendidikan di jalan Kartini Kota Salatiga Bangunan pendidikan pada kawasan jalan Kartini Kota Salatiga cenderung dikembangkan secara individu terpisah-pisah, lebih menekankan aspek fungsionalis tiap bangunan, namun dari analisa juga dapat disimpulkan bahwa ada usaha untuk bangunan-bangunan pendidikan di Jalan Kartini untuk saling terintegrasi, terlihat bangunan kelas dan bangunan sekolah latihan menjadi penghubung struktural massa pada kawasan bangunan tersebut.

Adapun rekomendasi atau saran yang dapat dijadikan masukan, yaitu: (a) Kepada lokus penelitian dalam pengembangan bangunan pada masa yang akan datang sebaiknya lebih memperhatikan konsep desain awal bangunan tersebut. Sebagai bangunan cagar budaya dengan karakter arsitektur kolonial modern; (b) Dalam pengembangan kawasan bangunan Pendidikan di Jalan Kartini akan lebih baik apabila pengembangan difokuskan sebagai sebuah kawasan pendidikan Kota Salatiga, sehingga ke depannya kawasan ini dapat menjadi sebuah kawasan pendidikan yang terintegrasi dengan baik; (c) Penelitian ini terbatas lebih kepada permasalahan deskriptif fisik (bangunan, arsitektural, dan lingkungan), sehingga akan lebih baik jika nantinya dapat dilanjutkan dengan melakukan penelitian ditinjau dari aspek lainnya. Diharapkan pula dapat dikembangkan penelitian lebih mendalam mengenai segi arsitektural pada lokus penelitian tersebut, mengingat penelitian masih terbatas pada aspek fisik bangunannya saja.

\section{Ucapan Terima Kasih}

Terima kasih kepada pihak SMP N 1 Salatiga, SMP N 2 Salatiga, SMA N 3 Salatiga, SD N Salatiga 05 dan Dishubkombudpar Kota Salatiga, serta seluruh pihak dan narasumber yang terlibat di dalam penelitian ini.

\section{Daftar Pustaka}

Bappeda dan Dishubkombudpar Salatiga. (2013). Daftar Inventaris Bangunan Cagar Budaya Kota Salatiga

Budiharjo, Eko(ed.). (1997). Jati Diri Arsitektur Indonesia. Bandung: Penerbit Alumni.

Crewell, John W. (tj. Achmad Fawaid). (2013). Research Design, Pendekatan Kualitatif, Kuantitatif, dan Mixed. Pustaka Pelajar

Dishubkombudpar Salatiga. (2013). Sejarah Bangunan Cagar Budaya Kota Salatiga

Feilden, Bernard M. (1994). Conservation of Historic Buildings. Oxford: Butterworth-Heinemen Ltd.

Faisal, Gun et al. (2014). Tipologi Pintu Rumah Tradisional Dusun Pucung Situs Manusia Purba Sangiran. Langkau Bentang, Vol. 1/No. 2/2014.

Firzal, Yohanes. (2011). Tipologi Bangunan Tua. Local Wisdom - Jurnal Ilmiah Online, Vol. 3/No. 2 Juli 2011.

Handinoto. (2010). Arsitektur dan Kota-Kota di Jawa pada Masa Kolonial. Yogyakarta: Graha Ilmu.

Lang, Jon. (2005). Urban Design, A Typology of Proceduresand Products. Oxford: Architectural Press.

Rodwell, Dennis. (2007). Conservation and Sustainibility in Historic Cities. Black Well Publishing. 


\section{Teknik, 36 (2), 2015, 119}

Supangkat, Eddy. (2010). Galeria Salatiga. Salatiga: Griya Media.

Trancik, Roger. (1986). Finding Lost Space, Theory of Urban Design. New York: Van Nostrand Reinhold Company.

Utomo, Tri Prasetyo. (2005). Tipologi dan Pelestarian Bangunan Bersejarah, Jurnal Seni Rupa STSI Surakarta, Vol. 2, No. 1 Januari 2005.
UU, R. N. (2010). Undang-Undang RI. No.11 Tahun 2010 tentang Cagar Budaya. Jakarta: Menteri Hukum dan Hak Asasi Manusia.

Wijanarka. (2001). Teori Desain Kawasan Bersejarah. Program Studi Teknik Arsitektur Universitas Palangkaraya. 